\title{
Evaluation of outdoor and indoor dust deposition as environmental pollution in Erbil province
}

\author{
F. H. Aziz ${ }^{1} \&$ J. J. Al-Dabagh ${ }^{2}$ \\ ${ }^{1}$ Biology Dept., College of Education/Scientific Depts., \\ Salahaddin University, Iraqi Kurdistan Region, Iraq \\ ${ }^{2}$ Environ. Dept., College of Science, Salahaddin University, \\ Iraqi Kurdistan Region, Iraq
}

\begin{abstract}
Since particulates are a sort of air pollution and seriously impact on environmental conditions, a considerable amount of programs to assess and control air pollution are regarded, since there are only a few studies on dust deposition in Iraq and since there have been drought conditions in last few years. In the Iraqi Kurdistan region, an experiment on dust accumulation as indoor and outdoor air pollution was undertaken in Erbil City and surrounding areas from November 2008 to April, 2009. The amount of deposited dry dust in the deferent studied location and surrounding area was between 9.1 and 48.3 gm.m ${ }^{2}$. per 2 months. The results revealed that the concentration of some chemical characteristics like total acidity, total alkalinity and sulphate ranged between 733, 50-88 and 15-180 $\mathrm{mg} / \mathrm{l}$ respectively. Also determining elements in accumulated dry dust such as nitrogen, phosphorus, potassium and sodium ranged from $20.3-95.3,6.3-2.06,8.02-66.7$ and $0.9-43.6 \mathrm{mg} / \mathrm{l}$ respectively. However, heavy metals including $\mathrm{Zn}^{+2}, \mathrm{Fe}^{+3}, \mathrm{Cr}^{+3}, \mathrm{CU}^{+2}$ and $\mathrm{Pb}^{+2}$ were at a range of $0.54-3.8,15.4-67.3,0.04-1.22,0.025-0.47$ and $0.21-2.17 \mathrm{mg} / 1$ respectively. Radiation levels ranged from 0.02 to $0.08 \mathrm{msv} / \mathrm{h}$ (mile sever/hour). Finally, the values of studied parameters - indoor and outdoor - of decomposed dust composition were not more than limited values or levels of most other countries.
\end{abstract}

Keywords: Erbil City, atmosphere, dust deposition, chemicals, trace and heavy metals, radiation. 


\section{Introduction}

The source of dust storm of the Iraqi Kurdistan region originates from the middle and southern desert of Iraq. There are five major regions where dust originates from: the Desert area, the southern coast of the Mediterranean Sea, north east of Sudan, the Arabian Peninsula lower Volga and north Cocas in Russia [1]. The dust has been coming to Erbil governorates from the middle and southern part of Iraq and the eastern Saudi Arabia deserts. Sand and dust storms in Iraq have laden the wind dust that is now pushing across the Gulf [2]. A few papers have been done on the dust deposition (dry deposition) either by local or foreign workers from Kuwait, Jordan and Syria. Only single papers were published in Iraq dealing with the dust deposition. Also, there is little information on dust deposition in other countries [3]. Countries covering the dry deposition and acid rain caused by storm and its transport from country to country for example from Iraq to Turkey and from Japan to other European countries and some Asian countries [4].

In the present time and in dry conditions, the phenomenon of dust storm either in the Iraqi Kurdistan region or in Iraq has increased. Therefore it has attracted various attentions [5]. However, little information is available on the quantity of dust emission from source. The aim of this study is the evaluation of dust deposition - outdoor and indoor - at different locations within Erbil City and some of its surrounding areas.

\section{Materials and methods}

In this study five locations were selected in Shorsh, Erbil-Kirkuk highway, ErbilMosul highway, Bahirka village and Erbil-Kirkuk highway indoor house, for experimental purposes referred to as sites 1,2,3,4 and 5 respectively. In the field for dust collection a bucket and funnel were used, they were fixed on the roof, afterwards the dust fall was collected and weighed every two months which was determined as recommended [6]. Total acidity was determined as dust fall flux [7]. Total alkalinity was determined in the laboratory by titration method. Sulphate $\left(\mathrm{SO}_{4}^{-2}\right)$ is a precipitate in an acidic medium after reacting with barium chloride $\left(\mathrm{BaCl}_{2}\right)$ [8]. For digestive purposes a certain amount of collected dust was at $120^{\circ} \mathrm{C}$ for $24 \mathrm{hr}$, the digest was made using $\mathrm{H}_{2} \mathrm{SO}_{4}$ and $\mathrm{H}_{2} \mathrm{O}_{2}$ to convert it to solution by filtration. Sodium $\left(\mathrm{Na}^{+}\right)$and potassium $\left(\mathrm{K}^{+}\right)$determined by flam photometer digital flame analyzer samples were prepared as described by Kalra [10]. Nitrogen was determined by the Kjeldahl method, as described by Ryan et al. [11]. Phosphorus was determined; using spectrophotometer method in 410 $\mathrm{nm}$, as described by Ryan et al. [11] and sample preparation was made as described by [10]. Magnesium $\left(\mathrm{Mg}^{+2}\right)$ was determined, using atomic absorption [11]. Heavy metals $\left(\mathrm{Cu}^{+2}, \mathrm{Fe}^{+3}, \mathrm{~Pb}^{+2}, \mathrm{Zn}^{+2}\right.$ and $\left.\mathrm{Cr}^{+2}\right)$ were measured by atomic absorption spectrophotometer model (PYE UNICAM SP9 atomic absorption spectrophotometer). Samples were prepared as described by [11]. Radiation determined by the instrument Jhazaka Red [12]. 


\section{Result and discussion}

A dust fall result in Kurdistan (Table 1) was $48.3 \mathrm{gm} / \mathrm{m}^{2}$ per 2 months, with an average of 23.6. The present results are compared to those of Naddafi et al. [13] who found that the dust fall in USA and Palestine were much lower than in the Kurdistan region, The reason for differences refers to the fact that Iraq is surrounded by deserts, there is a shortage of rain fall and drought. The maximum dust fall was recorded in the Erbil-Kirkuk highway during Mar. and Apr. 2009. The reason behind this result is the fact that along the Kirkuk highway there are many cement factories, less vegetative cover and wind direction.

Table 1: Mean dust fall (gm/ $\mathrm{m}^{2} / 2$ months) from November 2008 to April 2009.

\begin{tabular}{|c|c|c|c|c|c|}
\hline \multirow{2}{*}{$\begin{array}{l}\text { Sites of } \\
\text { study }\end{array}$} & \multicolumn{3}{|c|}{ Data of sampling of dust collection } & \multirow[b]{2}{*}{ Mean } & \multirow[b]{2}{*}{$\mathrm{SD} \pm$} \\
\hline & $\begin{array}{c}\text { Nov.-Dec. } \\
2008\end{array}$ & $\begin{array}{c}\text { Jan.-Feb. } \\
2009\end{array}$ & $\begin{array}{c}\text { Mar.-Apr. } \\
2009\end{array}$ & & \\
\hline 1 & 13.3 & 18.3 & 31.6 & 21.06 & 9.45 \\
\hline 2 & 15 & 26.6 & 48.3 & 29.9 & 16.9 \\
\hline 3 & 20 & 21.6 & 43.3 & 28.3 & 13.01 \\
\hline 4 & 23.3 & 35 & 30 & 29.43 & 5.8 \\
\hline 5 & 9.1 & 9.6 & 10 & 9.5 & 0.45 \\
\hline Mean & 16.14 & 22.22 & 32.64 & 23.6 & \\
\hline $\mathrm{SD} \pm$ & 5.592 & 9.45 & 14.8 & & 12.125 \\
\hline
\end{tabular}

In Syria, Jordan, Lebanon, northern Israel, and Southern Egypt dust fall occurs in both winter and spring [14]. During the period of this study, it was noticed that the dust fall occurred in every season in Iraq [15]. The amount of dust fall in Iran and India ranged from 3.0-91.3 g/ $\mathrm{m}^{2} / \mathrm{month}$ which are higher than that of the dust fall amount in Kurdistan region. In this study, the value of indoor dust fall was $9.1 \mathrm{~g} / \mathrm{m}^{2} / 2$ months and the minimum amount of dust fall recorded in Erbil-Kirkuk highway indoor house during Nov. and Dec. 2008. This result agrees with the study done in the western and southeastern part of Tehran by Pakseresht [16] who found the amount of dust fall was $17.97 \mathrm{~g} / \mathrm{m}^{2} / 2$ monthly.

The recorded maximum value of total acidity was $33 \mathrm{mg} 10.1^{-1}$ for indoors during Sept. and Dec. 2008. More indoor dust acidity than outdoor could be due to heat and cook fuel chemical composition and soil erosion $[17,18]$. The minimum value of $7 \mathrm{mg} 10.1^{-1}$ was observed at Erbil-Mosul highway during Mar. and Apr. 2009 (Table 2). This may be due to alkalinity particles in the atmosphere which are carried by wind from soil sources $[4,19,20]$.

Mostly alkalinity relates to hydroxides [22] carbonates and bicarbonate form such as borate, silicate and phosphate component [22]. The lowest dust value was recorded on the Shorsh and Erbil-Mosul highway $50 \mathrm{mg}$ 10.1-1 during Jan. 
Table 2: $\quad$ Mean concentration $\left(\mathrm{mg} \mathrm{CaCO}_{3} / \mathrm{l}\right)$ of total acidity of decomposed dust from November 2008 to April 2009.

\begin{tabular}{|c|c|c|c|c|c|}
\hline \multirow{2}{*}{$\begin{array}{c}\text { Sites of } \\
\text { study }\end{array}$} & \multicolumn{3}{|c|}{ Data of sampling of dust collection } & \multirow[b]{2}{*}{ Mean } & \multirow[b]{2}{*}{$\mathrm{SD} \pm$} \\
\hline & $\begin{array}{c}\text { Nov.- Dec. } \\
2008\end{array}$ & $\begin{array}{c}\text { Jan. - Feb. } \\
2009\end{array}$ & $\begin{array}{c}\text { Mar. - Apr. } \\
2009\end{array}$ & & \\
\hline 1 & 21 & 10 & 8 & 13 & 7 \\
\hline 2 & 22 & 19 & 9 & 16.66 & 6.806 \\
\hline 3 & 20 & 12 & 7 & 13 & 6.557 \\
\hline 4 & 26 & 14 & 16 & 18.66 & 6.429 \\
\hline 5 & 33 & 28 & 20 & 27 & 6.557 \\
\hline Mean & 24.4 & 16.6 & 12 & 17.667 & \\
\hline $\mathrm{SD} \pm$ & 5.3197 & 7.197 & 5.7008 & & 7.7613 \\
\hline
\end{tabular}

and Feb. 2009, this agrees with a low level of alkalinity and may contribute to the large amount of acidity [23]. The maximum value was $88 \mathrm{mg} 10.1^{-1}$ recorded at Erbil-Kirkuk highway during Mar. and Apr. 2009 (Table 3), this may be due to the arid region i.e. road from Erbil to Baghdad, which is poor in plant covers and the presence of cement factories and $\mathrm{CaCO}_{3}$ and $\mathrm{MgCO}_{3}$ along the road [18-24].

Sulphate is abundant in the form of soil mineral, sulphur gases in the atmosphere and presents in rain water $[11,25,26]$. Maximum indoor sulphur value was $180 \mathrm{mg} 10.1^{-1}$ recorded at the Erbil-Kirkuk highway indoor house during Sep. and Dec. 2008.

Also sulphate as a gas can enter the house with dust fall [27]. Sinclair et al. [28] stated that sulphate has the ability to attach with fine dust particles. The minimum value of $15 \mathrm{mg} 10.1^{-1}$ was recorded at Bahirka village during Mar. and Apr. 2009 (Table 4). This may be due to the absence of factories [11]. Pollutionspecies serves as a carrier for sulphate pollution [29, 30].

Sodium is present in certain silicate minerals, its level in non-saline soil is relatively low. The normal range of sodium in soil ranged from 0.2 to $15 \mathrm{mg} / \mathrm{l}$ [31]. In this study the minimum value of $0.9 \mathrm{mg} 0.3 .1^{-1}$ was measured at Erbil-

Table 3: $\quad$ Mean concentration $\left(\mathrm{mg} \mathrm{CaCO}_{3} / \mathrm{l}\right)$ of total alkalinity of atmospheric dust precipitation from November 2008 to April 2009.

\begin{tabular}{|c|c|c|c|c|c|}
\hline \multirow{2}{*}{$\begin{array}{c}\text { Sites of } \\
\text { study }\end{array}$} & \multicolumn{2}{|c|}{ Data of sampling of dust collection } & \multirow{2}{*}{ Mean } & SD \pm \\
\cline { 2 - 4 } & $\begin{array}{c}\text { Nov.- Dec. } \\
2008\end{array}$ & $\begin{array}{c}\text { Jan. - Feb. } \\
2009\end{array}$ & $\begin{array}{c}\text { Mar. - Apr. } \\
2009\end{array}$ & & \\
\hline 1 & 66 & 50 & 51 & 55.66 & 8.96 \\
\hline 2 & 56 & 58 & 88 & 67.33 & 17.92 \\
\hline 3 & 64 & 50 & 53 & 55.66 & 7.37 \\
\hline 4 & 59 & 51 & 51 & 53.66 & 4.618 \\
\hline 5 & 85 & 63 & 65 & 78.66 & 13.65 \\
\hline Mean & 66 & 54.4 & 61.6 & 60.066 & \\
\hline SD \pm & 11.33 & 5.85 & 15.8 & & 11.949 \\
\hline
\end{tabular}

$\operatorname{LSD}_{(0.01)}$ for studied sites $=21.45$ LSD $_{(0.01)}$ for sampling dates $=22.73$. 
Table 4: Mean concentration (mg/l) of sulphate $\mathrm{SO}_{4}^{-2}$ of atmosphere dust precipitation from November 2008 to April 2009.

\begin{tabular}{|c|c|c|c|c|c|}
\hline \multirow{2}{*}{$\begin{array}{c}\text { Sites of } \\
\text { study }\end{array}$} & \multicolumn{2}{|c|}{ Data of sampling of dust collection } & \multirow{2}{*}{ Mean } & \multirow{2}{*}{ SD \pm} \\
\cline { 2 - 5 } & $\begin{array}{c}\text { Nov.- Dec. } \\
2008\end{array}$ & $\begin{array}{c}\text { Jan. - Feb. } \\
2009\end{array}$ & $\begin{array}{c}\text { Mar. - Apr. } \\
2009\end{array}$ & & \\
\hline 1 & 88 & 45 & 25 & 52.66 & 32.192 \\
\hline 2 & 95 & 120 & 24 & 79.66 & 49.802 \\
\hline 3 & 65 & 78 & 26 & 56.33 & 27.061 \\
\hline 4 & 73 & 20.3 & 15 & 36.1 & 32.066 \\
\hline 5 & 180 & 130 & 33 & 114.4 & 74.741 \\
\hline Mean & 100.2 & 78.66 & 24.6 & 67.82 & \\
\hline SD \pm & 46.159 & 47.127 & 6.426 & & 48.3601 \\
\hline LSD & \multicolumn{3}{|c|}{ for studied sites $=120.6$, LSD } \\
\hline
\end{tabular}

Mosul highway during Nov. and Dec. 2008, this may be due to partial non salinity in the feed rain at northern Iraq, but it is very common in the irrigation water in central and southern Iraq [24]. The maximum value was $43.6 \mathrm{mg} \mathrm{0.3.1^{-1 }}$ recorded at the Erbil-Kirkuk highway during Jan. and Feb. 2009 (Table 5). Janitsky suggests that the high level of sodium may be due to the presence of large desert area and cement factories; that their dust might be carried by wind in southern and the middle part of Iraq.

Table 5: Mean concentration (mg/l) of sodium of atmosphere dust precipitation from November 2008 to April 2009.

\begin{tabular}{|c|c|c|c|c|c|}
\hline \multirow{2}{*}{$\begin{array}{c}\text { Sites of } \\
\text { study }\end{array}$} & \multicolumn{3}{|c|}{ Data of sampling of dust collection } & \multirow[b]{2}{*}{ Mean } & \multirow[b]{2}{*}{$\mathrm{SD} \pm$} \\
\hline & $\begin{array}{c}\text { Nov.- Dec. } \\
2008\end{array}$ & $\begin{array}{c}\text { Jan. - Feb. } \\
2009\end{array}$ & $\begin{array}{c}\text { Mar. - Apr. } \\
2009\end{array}$ & & \\
\hline 1 & 5.39 & 15 & 22.2 & 14.19 & 8.433 \\
\hline 2 & 5.39 & 43.6 & 31.2 & 26.73 & 19.493 \\
\hline 3 & 0.9 & 12.7 & 20.9 & 11.5 & 10.053 \\
\hline 4 & 5.39 & 12.8 & 22.6 & 13.59 & 8.632 \\
\hline 5 & 15.3 & 20.4 & 32 & 22.65 & 8.558 \\
\hline Mean & 6.47 & 20.9 & 25.78 & 17.718 & \\
\hline $\mathrm{SD} \pm$ & 5.303 & 13.069 & 5.357 & & 11.7054 \\
\hline
\end{tabular}

$\operatorname{LSD}_{(0.01)}$ for studied sites $=30.61, \operatorname{LSD}_{(0.01)}$ for sampling dates $=16.8$.

Potassium exists in soils in two forms; in the soil solution and at soil colloidal [18]. Temperature and moisture are important factors governing potassium abundance, the concentration range normally in soil extraction is from 5$50 \mathrm{mg} / \mathrm{g}$. [31]. Fine airborne particles cause a significant indoor source [28]. In

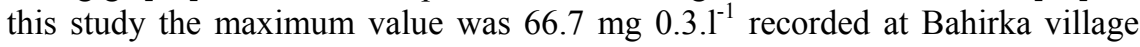
during Mar. and Apr. 2009 (Table 6), may be due to the nutrient addition to the soil for agricultural purpose. The minimum value of $\mathrm{K}^{+}$was $8.02 \mathrm{mg} 0.3 .1^{-1}$ recorded at the Erbil-Mosul highway site during Nov. and Dec. 2008 due to parent material and weathering variation, these results agree with the results of [33]. 
Table 6: Mean concentration (mg/l) of potassium of atmosphere dust precipitation from November 2008 to April 2009.

\begin{tabular}{|c|c|c|c|c|c|}
\hline \multirow{2}{*}{$\begin{array}{c}\text { Sites of } \\
\text { study }\end{array}$} & \multicolumn{2}{|c|}{ Data of sampling of dust collection } & \multirow{2}{*}{ Mean } & SD \pm \\
\cline { 2 - 5 } & $\begin{array}{c}\text { Nov.- Dec. } \\
2008\end{array}$ & $\begin{array}{c}\text { Jan. - Feb. } \\
2009\end{array}$ & $\begin{array}{c}\text { Mar. - Apr. } \\
2009\end{array}$ & & \\
\hline 1 & 8.76 & 21.8 & 46.6 & 25.72 & 19.22 \\
\hline 2 & 10.23 & 30.9 & 52.3 & 31.14 & 21.036 \\
\hline 3 & 8.02 & 34.3 & 37.7 & 26.67 & 16.243 \\
\hline 4 & 5.81 & 27 & 66.7 & 33.17 & 30.91 \\
\hline 5 & 20.1 & 41.9 & 59.7 & 40.56 & 19.833 \\
\hline Mean & 10.58 & 31.18 & 52.6 & 31.45 & \\
\hline SD \pm & 5.553 & 7.585 & 11.261 & & 19.4106 \\
\hline
\end{tabular}

$\operatorname{LSD}_{(0.01)}$ for studied sites $=56.98$, LSD $_{(0.01)}$ for sampling dates $=16.36$.

Nitrogen sources can be found in any cycle in nature. In the study the total nitrogen value ranged from 20.3-95.3 mg..$^{-1}$ at Bahirka village Nov.-Dec. 2008 and in Erbil-Kirkuk highway indoor house during Jan. and Feb. 2009 (Table 7).

Table 7: Mean concentration (mg/l) of nitrogen of atmosphere dust precipitation from November 2008 to April 2009.

\begin{tabular}{|c|c|c|c|c|c|}
\hline \multirow{2}{*}{$\begin{array}{c}\text { Sites of } \\
\text { study }\end{array}$} & \multicolumn{3}{|c|}{ Data of sampling of dust collection } & \multirow[b]{2}{*}{ Mean } & \multirow[b]{2}{*}{$\mathrm{SD} \pm$} \\
\hline & $\begin{array}{c}\text { Nov.- Dec. } \\
2008\end{array}$ & $\begin{array}{c}\text { Jan. - Feb. } \\
2009\end{array}$ & $\begin{array}{c}\text { Mar. - Apr. } \\
2009\end{array}$ & & \\
\hline 1 & 28.2 & 44.3 & 55.9 & 42.8 & 13.9 \\
\hline 2 & 26.09 & 37.2 & 46.6 & 36.63 & 10.266 \\
\hline 3 & 22.1 & 44.2 & 48.9 & 38.4 & 14.31 \\
\hline 4 & 20.3 & 32.6 & 53.5 & 35.46 & 16.78 \\
\hline 5 & 30.3 & 95.3 & 60.5 & 62.03 & 32.52 \\
\hline Mean & 25.39 & 50.72 & 53.08 & 43.066 & \\
\hline $\mathrm{SD} \pm$ & 4.16 & 25.407 & 5537 & & 19.14 \\
\hline
\end{tabular}

$\operatorname{LSD}_{(0.01)}$ for studied sites $=49.68$, LSD $_{(0.01)}$ for sampling dates $=29.37$.

The high recorded value may be due to the spill and usage of fuel for house warming [17]. Indoor released gases increase nitrogen gases and increase indoor total nitrogen amount compared with outdoor [37]. Generally, the nitrogen deposition patterns in the northeast are related to three factors which are distance from large emission sources, latitude and elevation [38].

The phosphorus concentration ranges normally encountered are given from soil extraction $0.3-8 \mathrm{mg} / 1$ [31]. In this study (Table 8 ) the maximum value of

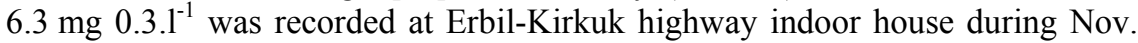
and Dec. 2008. Small particles can enter into the houses and settle as dust [49]. In this respect, the phosphorus content of the fine sand and clay fraction was $0.02-0.17 \%$ in the surface $5 \mathrm{~cm}$ of soil [34]. In the present study, the lowest value of $2.06 \mathrm{mg} 0.3 .1^{-1}$ was recorded at Bahirka village and the minimum value recorded may be due to a leaching factor by heavy rain fall in this area, whereas 
Table 8: Mean concentration (mg/l) of phosphor of atmosphere dust precipitation from November 2008 to April 2009.

\begin{tabular}{|c|c|c|c|c|c|}
\hline \multirow{2}{*}{$\begin{array}{c}\text { Sites of } \\
\text { study }\end{array}$} & \multicolumn{2}{|c|}{ Data of sampling of dust collection } & \multirow{2}{*}{ Mean } & \multirow{2}{*}{ SD \pm} \\
\cline { 2 - 4 } & $\begin{array}{c}\text { Nov.-Dec. } \\
2008\end{array}$ & $\begin{array}{c}\text { Jan.-Feb. } \\
2009\end{array}$ & $\begin{array}{c}\text { Mar.-Apr. } \\
2009\end{array}$ & & \\
\hline 1 & 5.68 & 2.13 & 2.18 & 3.33 & 2.035 \\
\hline 2 & 2.5 & 2.42 & 2.18 & 2.366 & 0.166 \\
\hline 3 & 2.8 & 3.32 & 3.1 & 3.0733 & 0.26 \\
\hline 4 & 2.06 & 2.28 & 2.2 & 2.18 & 0.111 \\
\hline 5 & 6.3 & 2.22 & 2.2 & 3.573 & 2.36 \\
\hline Mean & 3.868 & 2.474 & 2.372 & 2.904 & \\
\hline SD \pm & 1.967 & 0.484 & 0.407 & & 1.311 \\
\hline
\end{tabular}

$\operatorname{LSD}_{(0.01)}$ for studied sites $=49.68$, LSD $_{(0.01)}$ for sampling dates $=29.37$

organic phosphorus tends to increase and decrease with the content of organic matter and hence is comparatively low in subsoil and high in surface soils so phosphor is leached by heavy rain [35].

In this study more attention was paid to heavy metals $\left(\mathrm{Cu}^{+2}, \mathrm{Fe}^{+3}, \mathrm{pb}^{+2}, \mathrm{Zn}^{+2}\right.$ and $\mathrm{Cr}^{+2}$ ). The range of these metals was between $0.025-0.47,15.4-67.3,0.21-$ $2.17,0.54-3.8$ and $0.04-1.22 \mathrm{mg}^{-1} \mathrm{l}^{-1}$ as shown in (Tables 9-14). In the present study the concentrations of $\mathrm{Fe}^{+3}, \mathrm{Zn}^{+2}, \mathrm{Cu}^{+2}$ and $\mathrm{pb}^{+2}$ were higher in an indoor area due to the ability of these cations to attach with the finest particle and transfer to indoors $[39,40]$.

In this work lead was found in high concentration at Erbil-Mosul road due to fuel burn, the presence of emission was especially in very heavy traffic [41, 42]. Generally $\mathrm{Fe}^{+3}>\mathrm{Pb}^{+2}>\mathrm{Cu}^{+2}$ a similar order was observed in the work of Ayodele and Gimba [43]. Trace element results indicated that these elements increased during the dust storms [4], maybe originating from arid zones, or desert areas and from wave animation, coming by wind direction [44-48].

Table 9: $\quad$ Mean concentration (mg/l) of $\mathrm{Cu}^{+2}$ of atmosphere dust precipitation from November 2008 to April 2009.

\begin{tabular}{|c|c|c|c|c|c|}
\hline \multirow{2}{*}{$\begin{array}{c}\text { Sites of } \\
\text { study }\end{array}$} & \multicolumn{2}{|c|}{ Data of sampling of dust collection } & \multirow{2}{*}{ Mean } & \multirow{2}{*}{ SD \pm} \\
\cline { 2 - 4 } & $\begin{array}{c}\text { Nov.-Dec. } \\
2008\end{array}$ & $\begin{array}{c}\text { Jan.-Feb. } \\
2009\end{array}$ & $\begin{array}{c}\text { Mar.-Apr. } \\
2009\end{array}$ & & \\
\hline 1 & 0.24 & 0.209 & 0.025 & 0.158 & 0.116 \\
\hline 2 & 0.129 & 0.156 & 0.19 & 0.158 & 0.0305 \\
\hline 3 & 0.316 & 0.156 & 0.12 & 0.197 & 0.104 \\
\hline 4 & 0.129 & 0.183 & 0.08 & 0.13 & 0.0515 \\
\hline 5 & 0.31 & 0.47 & 0.22 & 0.333 & 0.1266 \\
\hline Mean & 0.225 & 0.235 & 0.127 & 0.195 & \\
\hline SD \pm & 0.0924 & 0.1333 & 0.079 & & 0.108 \\
\hline
\end{tabular}

$\operatorname{LSD}_{(0.01)}$ for studied sites $=0.242$ LSD $_{(0.01)}$ for sampling dates $=0.201$. 
Table 10: $\quad$ Mean concentration $(\mathrm{mg} / \mathrm{l})$ of $\mathrm{Fe}^{+3}$ of atmosphere dust precipitation from November 2008 to April 2009.

\begin{tabular}{|c|c|c|c|c|c|}
\hline \multirow{2}{*}{$\begin{array}{c}\text { Sites of } \\
\text { study }\end{array}$} & \multicolumn{2}{|c|}{ Data of sampling of dust collection } & \multirow{2}{*}{ Mean } & \multirow{2}{*}{ SD \pm} \\
\cline { 2 - 4 } & $\begin{array}{c}\text { Nov.-Dec. } \\
2008\end{array}$ & $\begin{array}{c}\text { Jan.-Feb. } \\
2009\end{array}$ & $\begin{array}{c}\text { Mar.-Apr. } \\
2009\end{array}$ & & \\
\hline 1 & 58.8 & 53.8 & 53.78 & 55.46 & 2.89 \\
\hline 2 & 58.2 & 15.4 & 51.3 & 41.63 & 22.97 \\
\hline 3 & 60.2 & 17.5 & 46.2 & 41.3 & 21.76 \\
\hline 4 & 57.4 & 65.5 & 46.8 & 56.56 & 9.377 \\
\hline 5 & 55.7 & 67.3 & 43.6 & 55.53 & 11.85 \\
\hline Mean & 58.02 & 43.9 & 48.33 & 50.09 & \\
\hline SD \pm & 1.606 & 35.59 & 4.116 & & 15.177 \\
\hline
\end{tabular}

$\operatorname{LSD}_{(0.01)}$ for studied sites $=40.72$, LSD $_{(0.01)}$ for sampling dates=28.9.

Table 11: Mean concentration (mg/l) of $\mathrm{Pb}^{+2}$ of atmosphere dust precipitation from November 2008 to April 2009.

\begin{tabular}{|c|c|c|c|c|c|}
\hline \multirow{2}{*}{$\begin{array}{c}\text { Sites of } \\
\text { study }\end{array}$} & \multicolumn{2}{|c|}{ Data of sampling of dust collection } & \multirow{2}{*}{ Mean } & \multirow{2}{*}{ SD \pm} \\
\cline { 2 - 4 } & $\begin{array}{c}\text { Nov.-Dec. } \\
2008\end{array}$ & $\begin{array}{c}\text { Jan.-Feb. } \\
2009\end{array}$ & $\begin{array}{c}\text { Mar.-Apr. } \\
2009\end{array}$ & & \\
\hline 1 & 0.21 & 0.54 & 1.56 & 0.77 & 0.703 \\
\hline 2 & 0.88 & 0.88 & 0.94 & 0.9 & 0.034 \\
\hline 3 & 0.54 & 0.88 & 2.17 & 1.196 & 0.85 \\
\hline 4 & 0.54 & 0.88 & 0.94 & 0.786 & 0.215 \\
\hline 5 & 0.34 & 0.88 & 0.94 & 0.72 & 0.33 \\
\hline Mean & 0.02 & 0.812 & 1.31 & 0.874 & \\
\hline SD \pm & 0.253 & 0.152 & 0.55 & & 0.479 \\
\hline
\end{tabular}

$\operatorname{LSD}_{(0.01)}$ for studied sites $=1.36$, LSD $_{(0.01)}$ for sampling dates $=0.69$.

Table 12: Mean concentration (mg/l) of $\mathrm{Zn}^{+2}$ of atmosphere dust precipitation from November 2008 to April 2009.

\begin{tabular}{|c|c|c|c|c|c|}
\hline \multirow{2}{*}{$\begin{array}{c}\text { Sites of } \\
\text { study }\end{array}$} & \multicolumn{3}{|c|}{ Data of sampling of dust collection } & \multirow[b]{2}{*}{ Mean } & \multirow[b]{2}{*}{$\mathrm{SD} \pm$} \\
\hline & $\begin{array}{c}\text { Nov.-Dec. } \\
2008 \\
\end{array}$ & $\begin{array}{c}\text { Jan.-Feb. } \\
2009 \\
\end{array}$ & $\begin{array}{c}\text { Mar.-Apr. } \\
2009\end{array}$ & & \\
\hline 1 & 0.54 & 1.39 & 1.59 & 1.173 & 0.557 \\
\hline 2 & 1.28 & 0.82 & 2.11 & 1.403 & 0.653 \\
\hline 3 & 1.56 & 1.54 & 0.98 & 1.36 & 0.329 \\
\hline 4 & 1.04 & 1.62 & 1.11 & 1.256 & 0.316 \\
\hline 5 & 2.8 & 3.8 & 1.38 & 2.66 & 1.216 \\
\hline Mean & 1.444 & 1.834 & 1.634 & 1.5706 & \\
\hline $\mathrm{SD} \pm$ & 0.845 & 1.142 & 0.414 & & 0.819 \\
\hline
\end{tabular}

$\operatorname{LSD}_{(0.01)}$ for studied sites $=1.82, \operatorname{LSD}_{(0.01)}$ for sampling dates $=1.65$. 
Table 13: Mean concentration (mg/l) of $\mathrm{Cr}^{+}$of atmosphere dust precipitation from November 2008 to April 2009.

\begin{tabular}{|c|c|c|c|c|c|}
\hline \multirow{2}{*}{$\begin{array}{c}\text { Sites of } \\
\text { study }\end{array}$} & \multicolumn{2}{|c|}{ Data of sampling of dust collection } & \multirow{2}{*}{ Mean } & \multirow{2}{*}{ SD \pm} \\
\cline { 2 - 4 } & $\begin{array}{c}\text { Nov.-Dec. } \\
2008\end{array}$ & $\begin{array}{c}\text { Jan.-Feb. } \\
2009\end{array}$ & $\begin{array}{c}\text { Mar.-Apr. } \\
2009\end{array}$ & & \\
\hline 1 & 0.04 & 0.186 & 0.68 & 0.302 & 0.33 \\
\hline 2 & 0.186 & 0.186 & 1.22 & 0.53 & 0.59 \\
\hline 3 & 0.46 & 0.32 & 0.42 & 0.4 & 0.072 \\
\hline 4 & 0.18 & 0.88 & 0.68 & 0.58 & 0.36 \\
\hline 5 & 0.33 & 0.46 & 0.95 & 0.58 & 0.32 \\
\hline Mean & 0.239 & 0.406 & 0.79 & 0.478 & \\
\hline SD \pm & 0.16 & 0.288 & 0.304 & & 0.338 \\
\hline
\end{tabular}

$\operatorname{LSD}_{(0.01)}$ for studied sites $=0.97$, LSD $_{(0.01)}$ for sampling dates $=0.5002$.

In relation to radiation, the dust and aerosol particles in the atmosphere influenced by radiation balance (diffusion, reflection and absorption) [49]. In the present study the maximum value recorded at Erbil-Kirkuk highway outdoor while the minimum value recorded at Erbil-Kirkuk highway house indoor. During this study no significant radiation was recorded [49] (Table 14).

Table 14: Mean concentration $(\mathrm{msv} / \mathrm{h})$ of radiation of atmosphere dust precipitation from November 2008 to April 2009.

\begin{tabular}{|c|c|c|c|c|c|}
\hline \multirow[b]{2}{*}{$\begin{array}{c}\text { Sites of } \\
\text { study }\end{array}$} & \multicolumn{3}{|c|}{ Data of sampling of dust collection } & \multirow[b]{2}{*}{ Mean } & \multirow[b]{2}{*}{$\mathrm{SD} \pm$} \\
\hline & $\begin{array}{c}\text { Nov.-Dec. } \\
2008\end{array}$ & $\begin{array}{c}\text { Jan.-Feb. } \\
2009\end{array}$ & $\begin{array}{c}\text { Mar.-Apr. } \\
2009\end{array}$ & & \\
\hline 1 & 0.04 & 0.06 & 0.04 & 0.046 & 0.0115 \\
\hline 2 & 0.04 & 0.02 & 0.03 & 0.03 & 0.01 \\
\hline 3 & 0.04 & 0.04 & 0.03 & 0.036 & 0.0057 \\
\hline 4 & 0.03 & 0.06 & 0.05 & 0.046 & 0.0152 \\
\hline 5 & 0.05 & 0.08 & 0.06 & 0.0633 & 0.0152 \\
\hline Mean & 0.04 & 0.052 & 0.042 & 0.044 & \\
\hline $\mathrm{SD} \pm$ & 0.007 & 0.022 & 0.013 & & 0.0155 \\
\hline
\end{tabular}

$\operatorname{LSD}_{(0.01)}$ for studied sites $=0.0313$ LSD $_{(0.01)}$ for sampling dates $=20.58$.

\section{Conclusion}

Based on the results of this study, the following conclusions can be drawn:

1 -Electrical conductivity value revealed that rain fall was rich in dissolved solids caused by dust deposition.

2-The water rainfall was rich in $\mathrm{Na}^{+}$and $\mathrm{K}^{+}$, while $\mathrm{Fe}, \mathrm{Cu}$ and $\mathrm{Mn}$ were not detected.

$3-\mathrm{Pb}$ and $\mathrm{Zn}$ values were in the range of $0.7-0.8 \mathrm{mg} / \mathrm{L}$.

4-The results indicate that the chemical properties of rainfall were mostly attributed to dust fall or dry deposition.

5-Indoor contamination is higher in most locations than outdoor dustfall. 
6-In dry deposition the normal level of recorded total acidity and alkalinity, heavy metals and free radiation was found.

7-Both rain and dust fall of the area was relatively unpolluted during the study period.

\section{References}

[1] Hasson A. (2008). Atmospheric dust properties and its effect on light transmission and crop-Soil productivity. J. Agricultural, Food, and Environmental Sciences, 2, pp. 1934-7235.

[2] Kazmi A. and Bureau, S. (2008). Dust Envelops USE, reducing Visibility and triggering breathing problems. The Nation cited from www. gulfnews. com.

[3] Xuan J.; Guoliang L. and Ke D. (2000). Dust emission inventory in Northern China. Atmospheric Environmen: 34, pp. 4565-4570. www. elsevier. com/ locate /atmosenv.

[4] Xiao-Ye Z.; An Z.; Liu D.; Chen T.; Zhang G.; Richard A.; Zhu G. and Wang X. (1992). Study on Three Dust Storms in China Source Characterization of Atmospheric Trace element and Transport Process of Mineral Aerosol Particles. Chinese Science Bulletin .37 (11).

[5] Lin, J. and M.A. (2005). Spatial and Temporal Modelling of Water Acidity in Turkey Lakes Watershed. MC Master University. Turkey.

[6] Krabteree G.W. (2005). Dust Full on the Southern High Plains. M.Sc. Thesis Univ. of Texas.

[7] APHA (1998). Standard Methods for the Examination of Water and Wastewater. 20th. Ed. American Public Health Association. 1015 Fifteenth Street. NW. Washington, DC. 200052605.

[8] Kapur P. and Sudha R.G. (2004). Experimental Plant Ecology. New Delhi. CBS Publisher. India.

[9] Rump, H.H. (1999). Laboratory Manual for the Examination of Water, West Water and Soil. $3^{\text {rd }}$ ed. Wiley. VCH. New York. pp. 181-193.

[10] Kalra Y.P. (1998). Reference Method for Plant Analysis. Taylor and Francis group, LLC., p. 153-155.

[11] Ryan J.; Estefon F. and Rashid A. (2001). Soil and Plant Analysis Laboratory Manual. $2^{\text {nd }}$ ed. National Agriculture Research Center (NARC) Islamabad, Pakistan.

[12] Snedecor, W.G. and Cochran G.W. (1980). Statistical methods. $7^{\text {th }}$ ed. The Iowa State Univ. Press, U.S.A. pp. 194-210.

[13] Naddafi, K.; Nabizadeh, R.; Soltanianzadeh, Z. and Ehrampoosh, M.H. (2006). Evaluation of Dust falls in the Air of Yazad, Iran J. Environ. Health Sci: Eng; 3(3):161-168.

[14] Kutiel H. and Hadar F. (2003). Dust Storms in the Middle East: Sources of Origin and their Temporal Characteristics. Indoor Built Environment; 12:419-426. 
[15] Thakur, M., and Kantideb. M (2000). Lead levels the air borne dust particulates of an urban city of central India.

[16] Env. Monitoring and quantity dust full in Southeast and west Tehran. Final Project for M. Sc.., Faculty of Environmental Health, Tehran University.

[17] WHO (World Health Organization) (1999). Indoor Air Pollution in the Eastern Mediterranean Region. Amman, Jordan.

[18] Brady N.C. (1974). The Nature and Properties of Soil. $8^{\text {th }}$ edition. MacMillan Publication, New York. USA. p. 639.

[19] Dimari, A.G.; Hati, S. S.; Waziri, M.; and Matira, O.N. (2008). Pollution synergy from Particulate matter source: The Harmattan, Fugitive Dust and Combustion Emission in Maiduguri Metropolis, Nigeria. Euro Journals. 22(3), pp. 465-473. http:// www.Eurojournals Com/ ejsr.htm.

[20] Zhang D., Jiaye Z., and Yasunobu I. (2002). Asian dust storm particles at Kingdom of China and their comparison with those collected from Japan. Nagya University. Japan.

[21] USEPA (United States Environmental Protection Agency) (2006). Air Quality Criteria for Particulate Matter. National Center for Environmental Assessment - RTP Office. U.S. Research Triangle Park, NC Vol.2. EPA / 600 / P-99 /002Sbf, pp.71-227.

[22] Yuzwa, G. and Eng, P. (1982). Alkalinity Reduction by Chloride from Anion Exchangers Albert Govern Servi. Water Treatment Coordinators Meeting.

[23] FRSC (Federal Road Safety Commission) (2008). Motorcycle registration dossier for 2006, 2007 to March 2008. FRSC Zonal Office, Maiduguri, Borno State.

[24] Buringh P. (1960). Soi and Soil Conditions in Iraq. Ministry of Agricultural. Baghdad. P. 322.

[25] Bartram, J. and Richared B. (1996). Water Quality Monitoring. WHO (World Health Organization) and UNEP (United Nations Environment Program). London. P 383 .

[26] Qadr N.S.K. (2006). Wastewater treatment using Typha angustifolia as a biological purifier.

[27] Seto, S.; Nakamura, A.; Noguchi, I.; Ohizumi, T.; Fukuzaki, N.; Toyama, S.; Maeda, M.; Hayashi, K. and Hara, H. (2002). Annual and seasonal trends in chemical composition of precipitation in Japan during 1989-1998. Atmospheric Environment. 36, pp. 3505-3517.

[28] Sinclair J.D.; Psoto-Kelty L.A. and Weschler C.J. (1985). Indoor/outdoor concentrations and indoor surface accumulation of Ionic substance. Atmospheric Environment., 19(12), pp.315-323.

[29] Bishop, J.K.B.; Davis, R.E. and Sherman, J. T. (2002). Robotic observation of dust storm enhancement of carbon biomass in the North pacific. Science. 298, pp. 817-820.

[30] Erel, Y.; Dayan, U.; Rout, R.Y. and Mordechi, F. (2006). Transboundary transport of pollutant by atmospheric Mineral dust. American Chemical Society. 4(9), pp. 2996-3005. 
[31] Allen, E.S. (1974) Chemical Analysis of Ecological Materials. Well Scientific Publication. USA.

[32] Dilimun, P.J. (1977). Reclamation of Salt Affected Soils in Iraq. Soil Hydrological and Agricultural Studies. ILRI (International Institute For Land Reclamation and Improvement). Northlands.

[33] Failyer G.H.; Smith J.G., and Wade H.R. (1908). The Mineral Composition of soil particles. U.S. Dept. Agr., Bur. Soils Bul. 54.

[34] Goel, K.N. and Agarwal, R.R. (1960). Total and organic phosphorus indifferent size. Fractions in genetically related soils of Kampur in the Indian Gangetic aluminum. Indian J. Soil Sc. 8, pp. 17-22.

[35] Patel, J.M., and Mehta B.V. (1961). Soil Phosphorus Fraction Studies. Soil Sci. Amer. Soc. Proc. 25, pp. 190-192.

[36] NADP (National Atmosphere Deposition Program) (2000). Nitrogen in the Nation's Rain. NADP Brochure. USA. Pp. 1-136. nadp.sws.uiuc.edu

[37] Fergusson, J. E. and Kim, N.D. (1991). Trace elements in street and house dusts: sources and speciation, Environ Sci., 100, pp. 25-150.

[38] Lambert, K.F. and Charles, D. (2004). Nitrogen Pollution from the Sources to the Sea. HBRF (Hubbard Brook Research Foundation). Hanover, Germany.

[39] Khillare P.S.; Balachandran S. and Bhart R.M. (2004). Spatial and Temporal Variation of Heavy Metals in Atmospheric Aerosol of Delhi. New Delhi. Environmental Monitoring and Assessment; 90 pp. 1-21.

[40] Baltrenas P., Kliaugiene E. (2003). Environmental impact on soil from transport system in various cities in Lithuania urban Transport IX: Urban Transport and the environment in the 21 st century. Great Britain IX, pp. 373-382.

[41] Taraskevicius R. and Radzevicius A. (1998). Contamination by heavy metals in type of soils; pp. 9, 10-11, 20-21.

[42] Adedokum, J.A.; Emofurieta, W.O. and Adedeji, O.A. (1989). Physical, mineralogical and chemical properties of Harmattan dust at Ile-Ife, Nigeria. Theor. Appl. Climatol. 40, pp. 161- 169.

[43] Ayodele, J.T. and Gimba, I.D. (2002). Heavy metals in air borne particulate dust Harmattan Kano- Northern Nigeria. Asset. Series B, (1:1) pp. 9-20.

[44] Chudnovsky A.A.; Ben-Dor E., and Saaroni H. (2007). Reflectance Spectroscopy of indoor settled dust in Tel Aviv, Israel: comparison between the spring and the summer season. Tel- Aviv University, Israel.

[45] Loy P., Freeman N., and Millette J. (2002). Dust a metric for use in residential and building exposure assessment and source characterization, Environ. Health Perspect. 110, pp. 969-983.

[46] Riley W.J.; McKone, T.M; Lai, A C K. and Nazaroff, W. (2002). Indoor particulate matter of outdoor origin: Importance of size-dependent removal mechanisms, Environ. Sci. Technol., 36, pp. 1868, 2002.

[47] Fellenberg G., (2000). The Chemistry of Pollution, $3^{\text {rd }}$ edition. John Wiley and Sons, LTD.

[48] Legrand, M. (1988), Satellite Detection of Saharan Dust: Optimized Imaging during Nighttime. Journal of Climate, 1(3), pp. 256-264. 
[49] Vallack H. and Shillito D. (1998) Suggested Guidelines for Deposited Ambient Dust, Atmos. Environ., 32(16), pp. 2737-2744.

[50] Soltan M.E., Rageh H.M., Rageh N.M. and Ahmed M.E. (2005). Experimental approaches and analytical technique for determining heavy metals in fallen dust at ferrosilicon production factory in Edfu, Aswan, Egypt. Zhejiang Univ. Sci. Biol,. 6(8), pp. 708-718. 